International Journal of Business and Management Review

Vol.8, No.2, pp.85-93, March 2020

Published by ECRTD-UK

Print ISSN: 2052-6393(Print), Online ISSN: 2052-6407(Online)

\title{
AGRICULTURAL BUDGETING IN ANAMBRA STATE: ITS' IMPLICATION FOR SUSTAINABLE ECONOMIC DEVELOPMENT
}

\author{
${ }^{1}$ Okeke, C.C. , ${ }^{1}$ Obianefo, C. A, \& ${ }^{1}$ Umebali, E. E \\ ${ }^{1}$ Department of Agricultural Economics \& Extension \\ Nnamdi, Azikiwe University, P.M.B 5025 Awka, Anambra State, Nigeria \\ E- mail: chinyere4cokeke@gmail.com
}

\begin{abstract}
This work was embarked upon with a view to determining agricultural budgeting over the years and its implication for sustainable economic development. Designed essentially as a descriptive survey, it is an ex-post-facto study. Secondary data used for the study were sourced from the official records and documents of Anambra State Government Nigeria. Data were analyzed using the time series components of trend and moving averages using E-view. Results indicated the following: there was no correspondence between estimated agricultural revenue and actual expenditure in the budget of Anambra State Government - hence large deficits were recorded. There was a mismatch between planned expenditure with remarkably high values that was observed in the Anambra State budget. The trend in the growth of actual agricultural expenditure over the period was upward sloping, rising slowly and steadily. The trend in the growth of actual revenue of the Anambra State Government budget over the period was upward sloping, rising sharply at first, and following an irregular pattern as it progresses. It was concluded that need outgrow availability of resources in Anambra State. However the fact remains that the problem was more of managerial than it was that of availability of resources. It is therefore recommended that, among other things, agricultural activities must be monitored so as to ensure proper implementation.
\end{abstract}

KEYWORDS: agricultural budgeting, sustainable development, Economic Development, Anambra State

\section{INTRODUCTION}

The evolution of budgeting over the past 100 years has influenced the practice of resource allocation and utilization in all countries especially in the developing countries (World Bank, 1998). The importance of budgeting in the growth and ultimately development of the economy cannot therefore be over-emphasized. Budgeting is the pivot on which the economy of any nation revolves. As such, it directs the path on which the economy treads. One of the basic principles of efficiency in management economics is budgeting which is conceptualized as rational allocation of resources. The efficiency, therefore, is predicated on a philosophy of scale of preference otherwise known as prioritization. The principle of budgeting presupposes a 
Vol.8, No.2, pp.85-93, March 2020

Published by ECRTD-UK

Print ISSN: 2052-6393(Print), Online ISSN: 2052-6407(Online)

system of rational distribution of available but scarce resources amongst the various competing needs. Another fundamental issue of principle of budgeting is matching expenditure with revenue, maintaining high employment and reasonable degree of stable price level otherwise known as stabilization. Beyond this, principle of budgeting is the consideration for broader, macro-economic variables such as, Gross Domestic Product (GDP), per capita income, capacity utilization, inflation, balance of payment, etc. All these form the major focus of budgetary decision. It implies that sound budgeting must be in conformity with the desired priority in macro-economic targets within the resource constraints. Obadan and Ogiogio (1995) define budget as governments' financial plan that covers its outlays and receipts. The budget typically will specify a list of programmes and projects as well as sources of financing them.

Nigeria is endowed with vast and largely untapped natural resources including such minerals as petroleum, iron-ore, tin, limestone, coal, natural gas, etc. Its vegetation is superb with a mix of high forest zone and savannah, which is mostly adapted for agricultural production. Nigeria has an area of land of 910.8 thousand square kilometers out of which 77.7 percent is cultivable (World Bank, 2016). There is also abundant water resources scattered in the States of the Nigerian nation. The country is made up of 36 (thirty-six) States of the federation with diverse tongues and tribes. However, a prominent feature of Nigeria is the homogenous nature of the States considering the diversity in culture and traditions. Unfortunately, Nigeria has been characterized by poverty, low life expectancy rate, high rate of maternal and infant mortality, educational backwardness, high rate of unemployment, etc. Agriculture is one of the key sectors that provide unrivalled opportunities for Nigeria's accelerated growth. It shares linkage with virtually all the sectors of the economy with proven multiplier effect on the economy. It remains Nigeria's surest most strategic and competitive way to secure her rapid industrialization and future. It creates employment more than any other sector of the economy, earns foreign exchange, provides food and food security, provide raw materials for our plants and industries. It is the basis of the Nigeria economic development (Suberu, Ajala, Akande and Olure-Bank 2015). Furthermore, diversification has a lot of benefits for Nigeria to maximally utilize her abundant resource - base to rebuild the economy and enjoy the benefits of all the linkages, synergy, economies of scale, grow national technology and foreign investment profile, build human capital, exploit new opportunities, lessen averagely operational costs, increase national competitiveness and grow the standard of living and confidence of the citizens for national renaissance. Adams (2016), in his study on the diversification of Nigerian economy through agricultural production showed that the contribution of agriculture to poverty reduction has a positive correlation and statistically significant at 1 percent $(\mathrm{p}=0.0001)$. i.e poverty can be reduced through agricultural production which contributes to economic development. Economic development implies a sustained increase in the output of goods and services followed by changes in technical and institutional arrangements through which output is produced and distributed. 
Vol.8, No.2, pp.85-93, March 2020

Published by ECRTD-UK

Print ISSN: 2052-6393(Print), Online ISSN: 2052-6407(Online)

Budgeting has been a tool for economic planning in Nigeria and in particular Anambra State. Each year, millions of naira will be doled out for projects and programmes which appear in annual budget. In recent time, there is a strong feeling that budgeting is a mere formality. This is partly because the desired economic growth and development has not been attained especially in the agricultural sector. The State is still characterized by low level of agricultural output that translate into vicious cycle of poverty, lack of basic social infrastructure, educational backwardness, high level of unemployment amongst others. There is also a mismatch of the social benefits of public expenditure and the social cost of withdrawal of resources from the private sector. Furthermore, there is paucity of information on budgeting in the study area as well as improved income of the rural households. This is the gap the study seeks to address. The problem of this study therefore, has been posed in question form. How sustainable is agricultural budgeting for economic development in Anambra State ?

Specifically, the study seeks to:

a.) ascertain the degree of correspondence between agricultural revenue and its' expenditure in Anambra State budget, and

b.) examine the trend in the growth of agricultural revenue in Anambra State Government budget.

c.) determine the effect of actual expenditure to the next year's financial budgeting

\section{METHODOLOGY}

The study was conducted in Anambra State, Nigeria. The State is located in the south-eastern part of Nigeria and lies between longitudes $6^{\circ} 40^{\prime} \mathrm{E}$ and $8^{\circ} 30^{\prime} \mathrm{E}$ and latitudes $5^{\circ} 45^{\prime} \mathrm{N}$ and $7^{\circ}$ $05^{\prime} \mathrm{N}$. The State has a land area of appropriately 4, 416 $\mathrm{km}^{2}$ (Anambra State ADP profile, 2003). It is situated on the low lands east of River Niger and is bounded to the west by Delta State, to the south by Imo and Abia States, to the north by Kogi State and to the east by Enugu State. The population of the State is $4,182,032$ (i.e. projection of 2.9 percent growth rate) with a population density of 947.02 persons per square kilometer (NPC, 2006). The number of farm families is estimated at about 338,000. The rainfall pattern is bimodal and there are basically two seasons: dry season and rainy season. Significantly enough, it derives its name from Anambra River, which itself is a tributary of the majesty River Niger; and situated on a rolling flat land on the eastern plains of the River Niger. The State covers an area of 4,416sq.km and has tropical, semitropical rain forest vegetation, a humid climate with a mean temperature of about $87^{\circ} \mathrm{F}$ and a rainfall regime of between $152 \mathrm{~cm}-203 \mathrm{~cm}$. There are few states in Nigeria, which have as many neighbours as Anambra State, sharing boundaries with Abia, Delta, Enugu, Imo and Kogi States. Because of the homogeneity of the Nigerian States, Anambra State has inherited most of the features and problems of the country. And so, budgeting in Anambra State has the same structure and system as Nigeria.The study was designed as a descriptive survey. Best and Kahn (1993) had recommended the use of descriptive survey when research efforts is focused on describing conditions and practice within any system. Secondary data was used for the study. The official 
records of Anambra State Government constituted the data. The time series data were analyzed using a software package of E-view. The time series components include trend and moving averages. Trend values were applied for determining the trend in the growth of agricultural revenues and expenditure over time. To estimate the effect of the actual expenditure to the next years' financial budgeting, E- view software package was used.

\section{RESULTS AND DISCUSSIONS}

Table 1: Degree of Correspondence of agricultural budget and actual expenditure (N' million), deviations and moving averages.

\begin{tabular}{llllll}
\hline YEAR & BUDGET & $\begin{array}{l}\text { 2-YEAR } \\
\text { MOVING } \\
\text { AVERAGES } \\
\text { (BUDGET) }\end{array}$ & ACTUAL & $\begin{array}{l}\text { 2-YEAR } \\
\text { MOVING } \\
\text { AVERAGES } \\
\text { (ACTUAL) }\end{array}$ & $\begin{array}{l}\text { SURPLS } \\
\text { (+) }\end{array}$ \\
& & & - & 184.69 \\
DEFICIT(- \\
\hline $\mathbf{2 0 0 0}$ & 267.80 & - & 83.11 & -69.34 & 152.88 \\
$\mathbf{2 0 0 1}$ & 208.50 & 238.15 & 55.63 & 69.34 & 179.92 \\
$\mathbf{2 0 0 2}$ & 246.70 & 227.60 & 66.78 & 61.22 & 127.87 \\
$\mathbf{2 0 0 3}$ & 198.00 & 222.35 & 70.13 & 68.46 & 130.77 \\
$\mathbf{2 0 0 4}$ & 219.08 & 208.54 & 88.31 & 79.22 & 237.40 \\
$\mathbf{2 0 0 5}$ & 456.90 & 337.99 & 219.50 & 153.91 & 495.45 \\
$\mathbf{2 0 0 6}$ & 607.71 & 532.30 & 112.26 & 165.88 & 1184.82 \\
$\mathbf{2 0 0 7}$ & 1439.82 & 1023.77 & 255.00 & 183.63 & 949.35 \\
$\mathbf{2 0 0 8}$ & 1250.25 & 1345.04 & 300.9 & 277.95 & 1399.83 \\
$\mathbf{2 0 0 9}$ & 1945.00 & 1597.62 & 545.17 & 423.04 & 760.00 \\
$\mathbf{2 0 1 0}$ & 1108.00 & 1526.50 & 348.00 & 446.58 & 526.00 \\
$\mathbf{2 0 1 1}$ & 1026.00 & 1067.00 & 500.00 & 424.00 & 602.31 \\
$\mathbf{2 0 1 2}$ & 1140.43 & 1083.22 & 538.13 & 519.06 & 1711.32 \\
$\mathbf{2 0 1 3}$ & 3151.44 & 2145.94 & 1440.12 & 989.12 & 3141.07 \\
$\mathbf{2 0 1 4}$ & 5704.87 & 4428.15 & 2563.80 & 2001.96 & 3872.62 \\
$\mathbf{2 0 1 5}$ & 4500.10 & 5102.48 & 627.48 & 1595.64 & 472.83 \\
$\mathbf{2 0 1 6}$ & 1159.59 & 2829.84 & 686.77 & 657.12 & -4632.62 \\
\hline $\mathbf{2 0 1 7}$ & 1424.17 & 1291.88 & 6056.80 & 3371.77 & \\
\hline
\end{tabular}

The result from table 1 above shows that there exist a mismatch between the agricultural budget and actual expenditure within the period under review. This is evidently clear from relatively large amount of deficit recorded. Also, the trend in the growth of agricultural budget was an initial rise; slowing down quickly and upward sloping up till 2008 and continued until 2016. 
Figure 1a: Graph of budget and actual expenditure in Agricultural sector
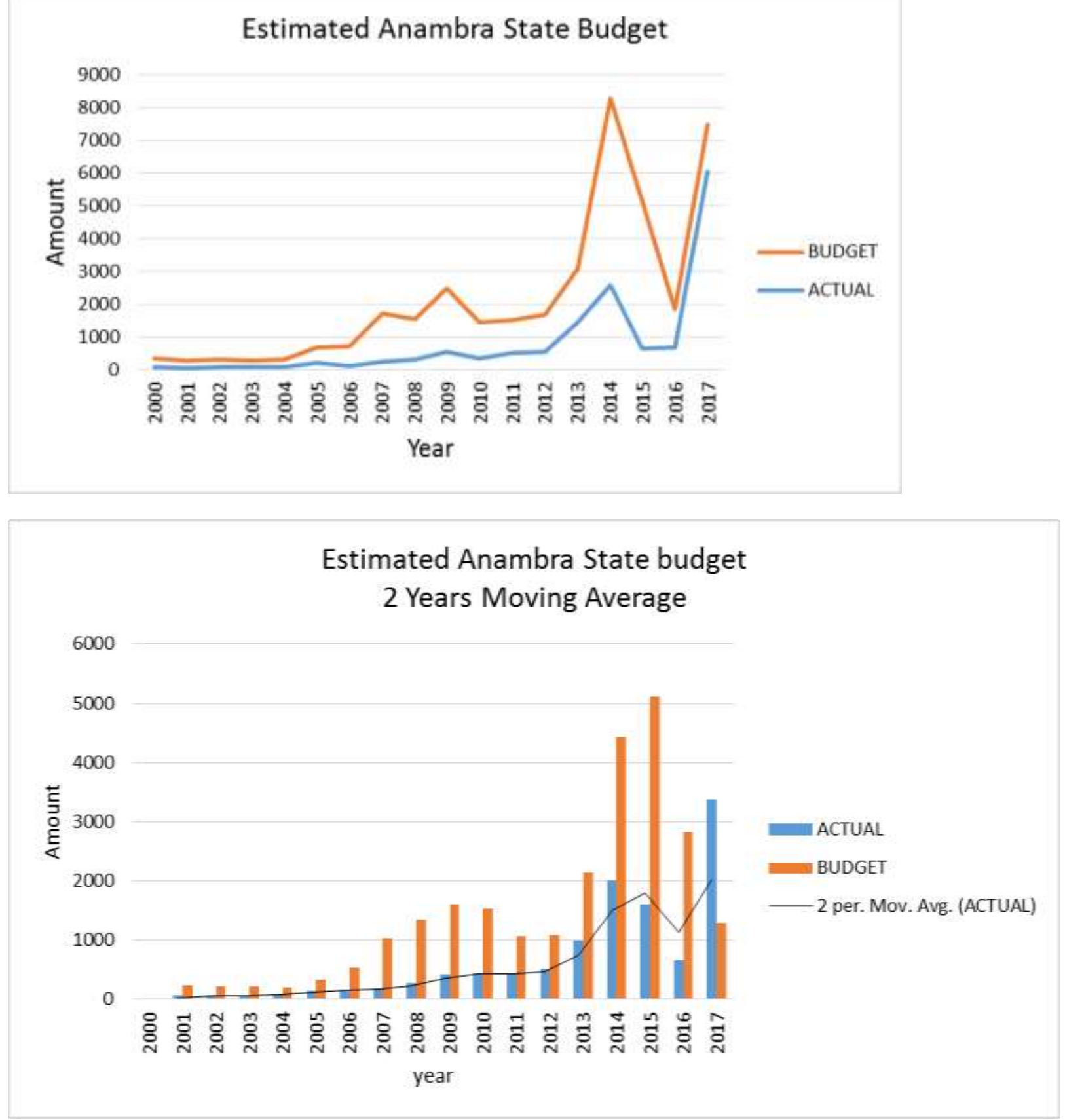

Figure 1b: Graph of budget and actual revenue in Agricultural sector 


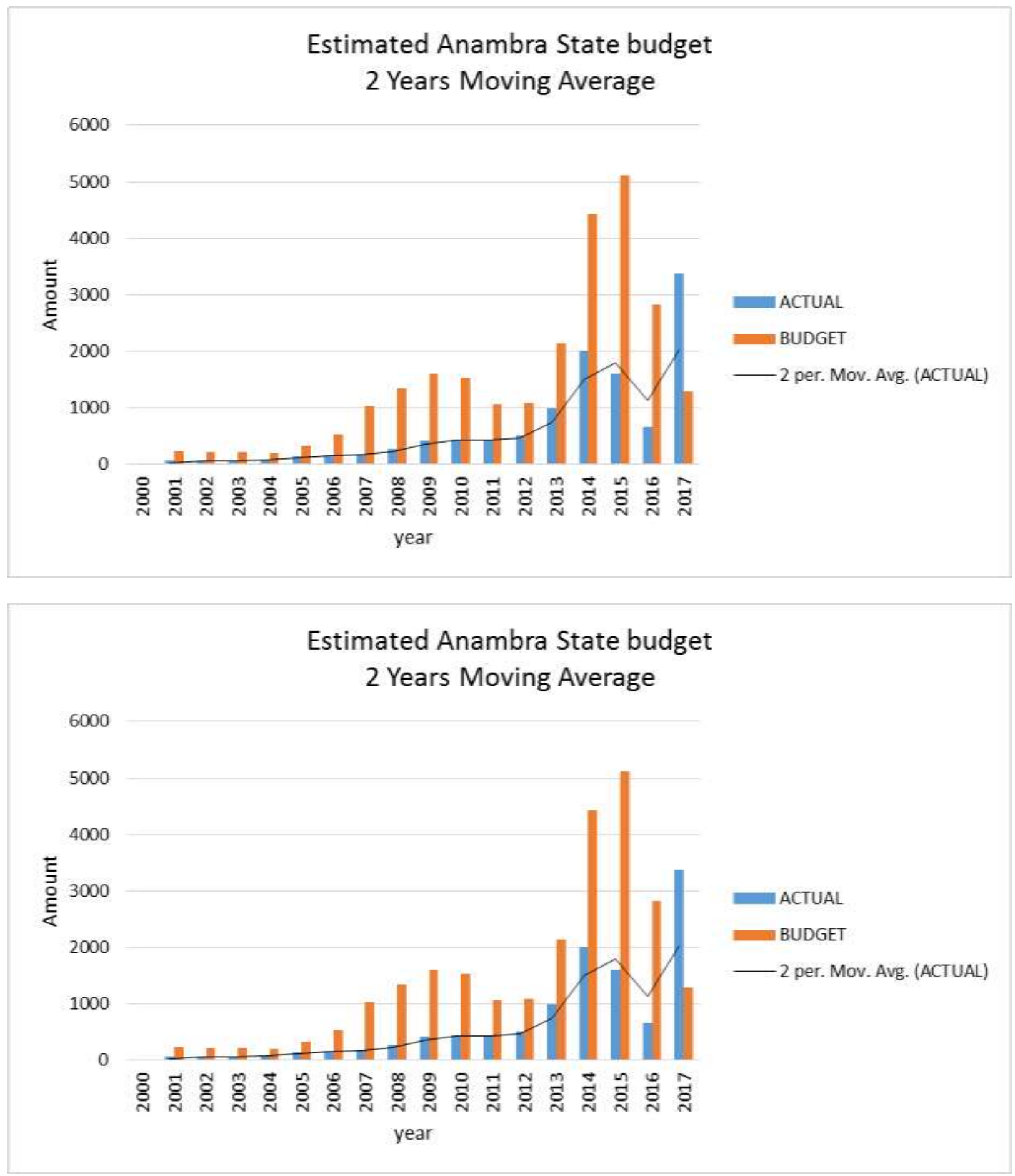


Vol.8, No.2, pp.85-93, March 2020

Published by ECRTD-UK

Print ISSN: 2052-6393(Print), Online ISSN: 2052-6407(Online)

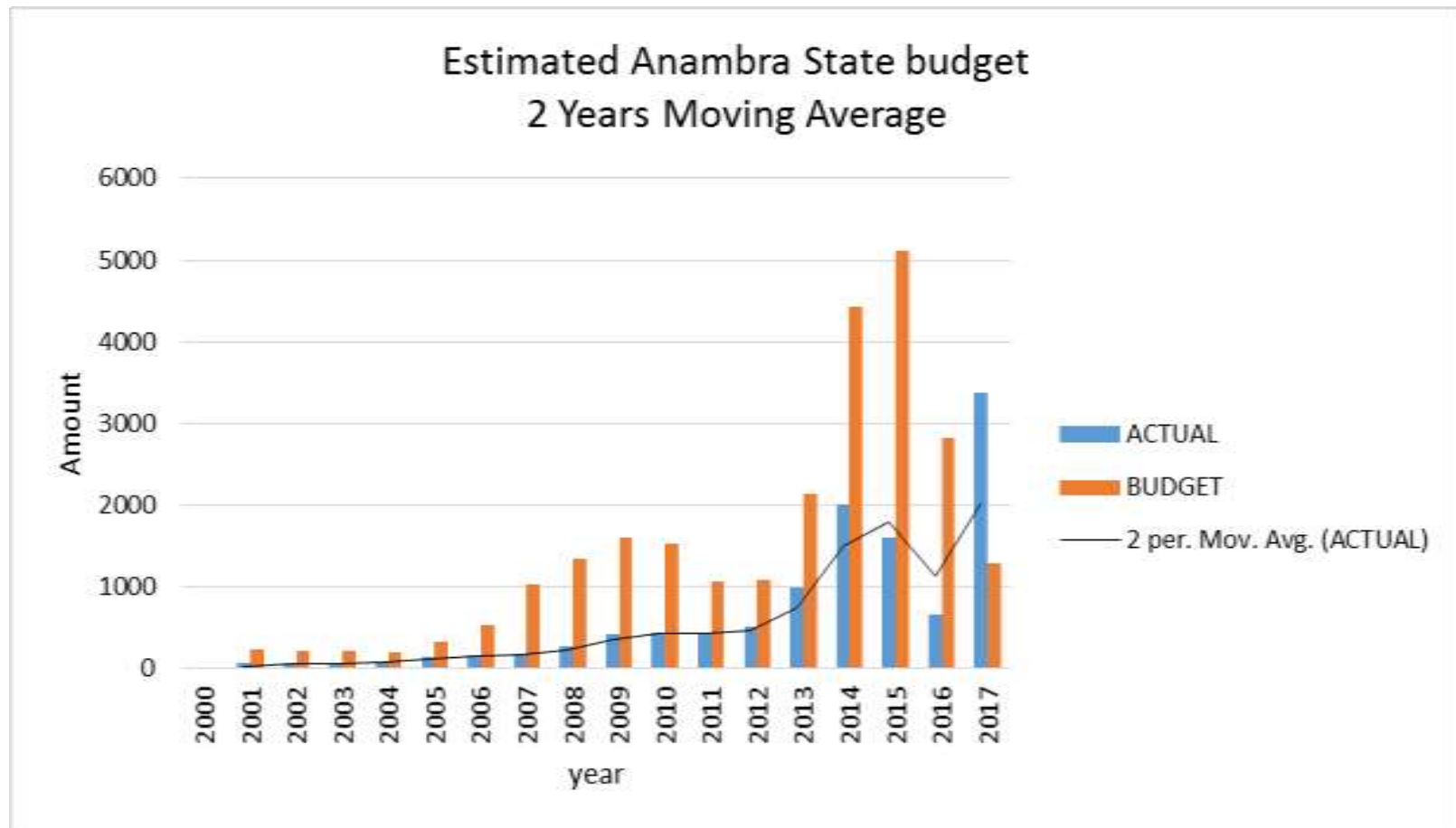

Figures $1 \mathrm{a}$ and $1 \mathrm{~b}$ were derived from table 1 . Figure $1 \mathrm{~b}$ was used to realize objective 2 . The figure shows that the trend in the growth of actual revenue over the period was upward sloping; rising rather quickly between 2007and 2010 and fluctuated in 2011 and 2012. It rises again sharply between 2013 and 2015 and gradually falls from 2015except for the sharp rise in 2017. The irregular pattern of growth in the actual revenue may be as a result of political instability experienced within these years as well as the incidence of corruption that has been ravaging the Nigeria economy. 
Vol.8, No.2, pp.85-93, March 2020

Published by ECRTD-UK

Print ISSN: 2052-6393(Print), Online ISSN: 2052-6407(Online)

Table 2: Effect of actual expenditure to the next year's financial budgeting Dependent Variable: LOGBUDGET

Method: Least Squares

Sample: 118

Included observations: 18

\begin{tabular}{lllll}
\hline \hline Variable & \multicolumn{2}{l}{ Coefficient Std. Error } & t-Statistic & Prob. \\
\hline \hline C & 1.259843 & 0.283832 & 4.438690 & 0.0004 \\
LOGACTUAL & 0.670178 & 0.110231 & $*$ & 0.0000 \\
\hline \hline R-squared & 0.697904 & Mean dependent var & 2.944594 \\
Adjusted R-squared & 0.679023 & S.D. dependent var & 0.459883 \\
S.E. of regression & 0.260546 & Akaike info criterion & 0.252362 \\
Sum squared resid & 1.086145 & Schwarz criterion & 0.351292 \\
Log likelihood & -0.271259 & Hannan-Quinn criter & 0.266003 \\
F-statistic & 36.96330 & Durbin-Watson stat & 0.904375 \\
Prob(F-statistic) & 0.000016 & & & \\
\hline \hline
\end{tabular}

Least Square Regression of the form: $\log ($ budget $)=c+d^{*} \log ($ actual $)$, was used to determine the effect of the actual expenditure on next year's financial budgeting in Anambra state. The table shows that the coefficient $(0.670178)$ of the log of actual expenditure was statistically significant at $1 \%$ level of probability. This implies that for every one unit change (decrease or increase) in actual expenditure, the estimated annual budget was either increased or decreased by 0.670178 . This was expected due to irregular pattern of the budget trend. The coefficient of multiple determinant $\left(\mathrm{R}^{2}\right)$ was 0.697904 , an indication that $69.79 \%$ of the regressand (Estimated Budget) was explained or regressed by the regressor (Actual Expenditure). The Durbin-Watson statistics of 0.904 shows that there was no autocorrelation.

\section{CONCLUSION}

Sustainable development can only be achieved especially in agricultural sector only when the funds earmarked for improved agricultural projects are utilized for the purpose it was meant for. This is only achievable by having the right attitude towards public funds; and having love for agricultural production so as to increase productivity and break vicious cycle of poverty. An effective partnership between government, actors and agent in agricultural sector in exploiting abundant human and material resources especially, land will undoubtedly put Nigeria on the part of sustainable growth and development. It is recommended as follows: there must be a monitoring of agricultural activities to ensure proper and effective budget implementation, the expansion of agricultural output through the increase in the agricultural budgets for agricultural production, adequate access to agricultural inputs and resources such as land and credit by 
Vol.8, No.2, pp.85-93, March 2020

Published by ECRTD-UK

Print ISSN: 2052-6393(Print), Online ISSN: 2052-6407(Online)

farmers, stimulates and diversify the domestic production of agricultural output and exportation of produce. Since the study discovered a mismatch between agricultural budget and actual expenditure, it shows that the implementation process was either not properly monitored or no monitoring was done at all; hence no documentation in this regard. Investment in agriculture should receive high priority and there is need for long term strategic plans for research and development as this will have significant impact on productivity growth. In the words of Iwo (2019), there is an urgent need for a fundamental shift in national and donor policies; funds for agriculture should increase many folds and this should be used in supporting small - scale farmers who are the main source of food for the world hunger. There should be proper monitoring of these resources committed so as to earn the desired agricultural development.

\section{References}

Adams, O. K. (2016). Diversification of Nigeria Economy through Agricultural Production. IOSR Journal of Economics and Finance (IOSR-JEF)..Volume 7, Issue 6 Ver. III (Nov. Dec. 2016), PP 104-107. www.iosrjournals.org

Anambra State Government (2000- 2017). Approved Estimates of Anambra State of Nigeria. The Government Printer, Awka.

Best, J.W. and Kahn, J.V. (1993). Research Education: New Delhi, Prentice Hall of India Private Limited.

Iwo, G. A. (2019). Authentic agriculture for sustainable food security in the global food system. A keynote address presented at the International conference on sustainable agriculture, organized by the International centre for integrated development research held at University of Uyo Akwa Ibom State, Nigeria.

Obadan, M.I and Ogiogio, G.O. (1995). Planning and Budgeting in Nigeria. NCEMA, Ibadan, Nigeria.

Suberu, O.J; Ajala, O.A; Akande, M.O, and Olure-Bank, A (2015). Economy towards a Sustainable Growth and Economic Development. International Journal of Economics, Finance and Management Sciences. Vol. 3, No. 2, 2015, pp. 107-114. doi: 10.11648/j.ijefm.20150302.15

World Bank (2016). Diversification of Nigerian economy: Agriculture and solid minerals as a panacea. In CBN bullion- a publication of Central Bank of Nigeria during its' $40^{\text {th }}$ anniversary. Vol.1 - 40 . 